\title{
Chapter 15 \\ Narrative Structures, Narratives of Abuse, and Human Rights
}

Diana Tietjens Meyers

Abstract A number of late 20th- early 21 st century political and intellectual movements put a spotlight on the value of listening to silenced voices. Picking up on these trends, philosophers have addressed a number of pertinent themes, including respect, empathy, and credibility. Less thoroughly explored is the relation between victims' stories and normativity. This paper examines two theories of narrative one by Hayden White and the other by Anthony Amsterdam and Jerome Bruner and argues that neither adequately accounts for the capacity of victims' stories of abuse to advance understanding of and increase respect for human rights. To better appreciate the contribution of victims' stories to human rights advocacy, I propose an account of the relation between normativity and a type of fractured story that traumatized victims often tell.

Keywords Human rights $\cdot$ Narrative $\cdot$ Victims $\cdot$ Moral closure $\cdot$ Systematic injustice

A number of late 20 th- early 21 st century political and intellectual movements put a spotlight on the value of listening to silenced voices. In consciousness raising sessions, second wave feminists exchanged stories of their everyday lives and used these stories to construct theories of gender and to formulate political agendas. ${ }^{1}$ Soon women of color and lesbians in western as well as developing nations objected that middleclass white feminists had silenced them and consequently misrepresented womanhood and the needs of women as a group. ${ }^{2}$ In law schools, critical race theorists made the case that white supremacy could not be eradicated unless personal stories of racial oppression were injected into U.S. legal proceedings. ${ }^{3}$ Recent truth commissions in South Africa and Peru and war crimes tribunals in the Hague and Rwanda have reaffirmed the right to a voice of one's own.

\section{D.T. Meyers $(\otimes)$}

Ignacio Ellacuria SJ Chair of Social Ethics and Professor of Philosophy Loyola University, 6525 N. Sheridan Road, Chicago, IL 60626-5385

e-mail: meyersdt@earthlink.net 
1. Respect - demonstrating respect for victims and helping them restore their sense of self and agency by establishing fora in which they can safely tell their stories. $^{4}$

2. Empathy - the capacity of victims' stories to elicit concern for different others and to mobilize compassionate responses to their plights. ${ }^{5}$

3. Credibility - the epistemic grounds for believing or doubting victims' stories. ${ }^{6}$

Less thoroughly explored is the relation between victims' stories and normativity. As a contribution to understanding how the stories of those who have been abused or oppressed can advance moral understanding, catalyze moral innovation, and guide social change, this paper focuses on narrative as a variegated form of representation and asks whether personal narratives of victimization play any distinctive role in human rights discourse.

In view of the fact that a number of prominent students of narrative build normativity into their accounts, it might seem obvious that there is a connection between victims' stories and moral insight. ${ }^{7}$ However, the category of victims' stories spans an enormous variety of texts - private diaries, memoirs written for publication, interviews with journalists or social scientists, depositions prepared by human rights workers, stories shared with like-minded activists or with support groups, stories told to medical professionals, and testimony in courts, truth commissions and asylum hearings, to mention just some of the possibilities. ${ }^{8}$ The different contexts of elicitation and the different rules governing expression in these sites should make us wary of ready generalizations about the nature of victims' narratives.

Moreover, I doubt that existing explications of the way in which norms figure in narratives yield satisfactory theories of the contribution victims' stories can make to discovering and defending just policies and practices. I consider two of the most prominent accounts of the relation between narrative and normativity. For different reasons, the account Anthony Amsterdam and Jerome Bruner present in their work on narrative and law (2000) and the account Hayden White presents in his work on narrative and history (1987) fail to appreciate the capacity of victims' stories of abuse to advance understanding of and increase respect for human rights. In defense of the value of victims' stories, I propose an account of the relation between normativity and a salient type of victim's narrative that seems especially resistant to integration into human rights discourse.

\subsection{The Amsterdam/Bruner Account of Narrative}

Anthony Amsterdam and Jerome Bruner adopt a conception of narrative that is deeply indebted to Aristotle's Poetics; A narrative

needs a cast of human-like characters, beings capable of willing their own actions, forming intentions, holding beliefs, having feelings. It also needs a plot with a beginning, a middle, and an end in which particular characters are involved in particular events. The unfolding of the plot requires (implicitly or explicitly):

1) an initial steady state grounded in the legitimate ordinariness of things

2) that gets disrupted by a Trouble consisting of circumstances attributable to human agency or susceptible to change by human intervention,

3 ) in turn evoking efforts at redress or transformation, which succeed or fail,

4) so that the old steady state is restored or a new (transformed) steady state is created,

5) and the story concludes by drawing the then-and there of the tale that has been told into the here-and now of the telling through some coda. $(2000,113-114)$

Despite Amsterdam and Bruner's talk of redress and transformation, their account is structurally conservative because they conceive of norms as culture-dependent conventions, and narratives that conform to their account are riddled with localized norms. As a result, I argue, their view is inhospitable to many victims' stories.

Each of Amsterdam and Bruner's key conceptions - the steady state, trouble, and emplotment - is normatively tinctured, in my view, perniciously so. The steady state that constitutes the beginning of a narrative is whatever people at that place and time regard as 'legitimate ordinariness' or as 'normatively valued states of affairs' (2000, 121; also see Bruner 2002, 6). But if a narrative can't get started without positing a condition of acceptable normality, many victims have no social history from which to speak. The very conditions that others regard as legitimate and ordinary are the cause of their misery. Consider U.S. slaves in 1700. No description of legitimate ordinariness in their ancestral homelands would have struck a chord with a sizable audience of powerful listeners (Mills 1998, Chapter 6). Women's subordination is even less amenable to being cast in the Amsterdam/Bruner framework. There never has been a society in which gender equality was institutionalized and deemed to be legitimate. To assume, then, that people live in a world of legitimate ordinariness until 'Trouble' crops up wrenches the tool of narrative out of the hands of many victims of human rights violations.

Equally worrisome is the pressure that the orthodoxy of the Amsterdam/Bruner model exerts on activists and sympathetic scholars to envisage an original state of legitimate ordinariness. Some Afrocentrist thought presents an unduly rosy picture of pre-colonial African tribal life that the slave trade and other colonial violence wrongly despoiled. Some feminist thought makes poorly supported claims about the existence of an ancient, forgotten matriarchy that was balefully supplanted by patriarchy. To plug African-Americans' story of racial injustice or women's story of gendered injustice into the Amsterdam/Bruner model, it is necessary to posit prior legitimate steady states, whether or not they can be documented. Later, I'll argue that the strategy of invoking a legitimate past state of affairs is liable to have unintended unjust consequences. For now, I conclude only that meeting the demands of the Amsterdam/Bruner model can override truth by prompting narrators to manufacture beginnings for their stories that are too good to be true.

Within the confines of this model, the only alternative is to appeal to an imaginary state of peace and justice - say, the international community's conception of legitimate ordinariness - and to project it onto the pre-Trouble circumstances of the victims. But I doubt that such a maneuver is necessary, and I suspect that it might 
prove counterproductive. Consider the genocide that commenced in Darfur in 2003. Virtually any conditions of life would be better than the attacks and deprivations the victims are now enduring. Indeed, the predominant rhetoric of moral outrage over this ongoing tragedy does not point to a pre-genocidal state of affairs that the victims took to be legitimate. Journalists and activists simply tell the story of what's going on - the unrelenting campaign of murder, rape, and arson against a defenseless people that is still underway in 2009. Later I'll argue for the moral power of non-classical forms of story-telling. For now, I merely suggest that incorporating human rights issues into a story does not necessitate conformity to Amsterdam and Bruner's account. ${ }^{9}$

Amsterdam and Bruner's conception of trouble is also prejudicial. That they capitalize trouble throughout their text is more than a typographical flourish. In their usage, 'Trouble' is the name of the set of sanctioned wrongs in a particular society or in a determinate international community. As they put it, "trouble takes off from what is canonical or moral or taken as the accepted and orderly set of things. And it is precisely this canonicity... that gives Trouble its orderliness and systematicity' (2002, 131; also see 121). But if a society's canonical state of affairs includes systematic injustice to some people, the victims will be barred from articulating their troubles. Their plans haven't 'gone off the track,' nor have their expectations 'gone awry' $(2002,31,135)$. They understand perfectly well how things work. They expect abuse and suffering, and they get it. Their troubles haven't made it into the lexicon. From a historicized human rights point of view, conceiving rights violations as 'Troubles' is at best naive, for this conception of narrative complication denies abuses that do not yet have official designations.

Once set in motion, the plot unfolds according to a 'stock script,' sometimes called a 'charter narrative' $(2000,121,127)$. Stock scripts supply models of normality, wrongful disruptions, and fitting remedies, and they identify the kinds of obstacles that thwart different human purposes $(2000,121,127)$. All of this is encoded in a culture's repertoire of genres - its 'mental models representing possible ways in which events in the human world can go' $(2000,133)$. Well-known genres include tragedy, comedy, and romance. Amsterdam and Bruner regard the conceptions of actionable causes that are inscribed in common law writs as 'legal genres' (2000, 133; also see Bruner 2002, 20, 58). As 'tools of narrative problem solving,' genres dictate how the story should proceed and how it should end - that is, what the protagonist should do in response to the trouble and whether the protagonist's complaints should be credited or dismissed $(2000,133)$.

Presupposing, as it does, authoritative precepts about who can be injured, this conception of emplotment instates a traditional paradigm of who has standing to protest wrongdoing by making legitimate claims - who is entitled to speak. Presupposing, as well, authoritative precepts that define how people can be harmed, it endorses a set of resolutions that may overlook the needs and life trajectories of unrecognized victims - those whose speech is preempted. Offering little solace to voiceless victims of human rights abuses, Amsterdam and Bruner's view of narrative plot diagnoses a problem for human rights advocates rather than proffering a solution.

\subsection{Narrative Regimentation, Exclusion, and Denial}

I have isolated the principal barriers to bringing victims' stories into human rights discourse that are erected by Amsterdam and Bruner's account of narrative. The picture is bleak, but not quite as bleak as one might surmise from my comments so far. Canny human rights activists help victims to craft their stories in conformity with this model because people who are in a position to help are comfortable with this type of story.

In stories collected to solicit donations from westerners, former male child soldiers in Sierra Leone tell a three part tale of youthful innocence, abduction and forced killing, and hoped-for rehabilitation (Shepler 2006). The boys invoke a legitimately ordinary childhood cut short by the horrific trouble of kidnapping and coerced participation in atrocities. No longer under the control of their captors, they now express a single-minded desire to return to their families. Moved by the dissemination of these stories, affluent western audiences have poured funds into aid agencies to educate and provide medical care for these boys.

As much as this narrative strategy has alleviated the suffering of these children and helped them resume nonviolent lives, it also incurs substantial costs. One is an invidious gender disparity. Former female child soldiers are not telling this story, and they have no other story to tell. Because the abducted girls were raped as well as forced to commit atrocities, they are not candidates for rehabilitation in their communities unless they conform to cultural norms that above all mandate female marriage by adopting a strategy of secrecy (Shepler 2002, 11). Consequently, their stories are suppressed, and the model of reintegration that structures humanitarian publicity and aid projects is grounded in the needs and possibilities of boys (Shepler $2002,7,9) .{ }^{10}$ The stories the boys tell, aided and abetted by human rights workers, together with the funds these stories attract perpetuate the girls' silence. Thus, Shepler calls on international aid organizations to reflect critically on the meaning of 'successful reintegration' into societies that are so unjust to women and girls (Shepler 2002, 16).

It is troubling as well that the boys' stories omit a great deal, and what they omit is not unimportant. The premise of childhood innocence from which these stories proceed invites audience distortion. For ignorant westerners, this story conjures up an image of a carefree childhood protected from harsh reality. But these boys never experienced anything like this idyllic youth. Not coincidentally, the boys' stories leave out the unjust conditions that shape their own lives and that also give rise to Africa's devastating wars. ${ }^{11}$ Their stories mask grave, endemic injustice for the sake of scoring short-term benefits. More shocking to their western benefactors, no doubt, is the omission of the children's complicity in murderous warfare. Some boys report, for example, that they 'enjoyed' firing their weapons (Shepler 2006). Accuracy in testimonial records and audience comprehension of Africa's problems are casualties of the bowdlerized texts that westerners are receptive to hearing and that local cultures find tolerable.

I am skeptical that the Amsterdam/Bruner model can be adapted to avoid these losses. Yet this model is all but irresistible in emergency human rights campaigns 
and in legal proceedings following grievous human rights violations. In these situations, producing a compelling case for aid or indisputable evidence of wrongdoing dictates tailoring victims' stories to fit into standardized formats and scripts that capitalize on moneyed or official listeners' preconceptions and do not jar their sensibilities. It appears, then, that the principal mechanisms of relief for victims do grave damage to truth and justice. Truth commissions give victims leeway to make more complete statements, to frame them in their own terms, and to utter them in their own style. However, truth commissions do not mete out traditional forms of justice - they neither compensate victims nor punish perpetrators of abuse. ${ }^{12}$

Because many victims of the worst abuses are not able or not willing to cast their experience in the narrative template Amsterdam and Bruner present, I take up an alternative approach to narrative. In what follows, I sketch Hayden White's theory of narrative, and then I consider whether White's account provides a satisfactory discursive home for mold-breaking victims' stories.

\subsection{Hayden White's Account of Narrative and Closure}

In 'The Value of Narrativity in the Representation of Reality,' Hayden White distinguishes three types of historical representation - annals, chronicles, and proper histories (1987, 4-5). An annalist furnishes nothing more than a list of dated events arranged in the order in which they occurred $(1987,5)$. No reason for the selection of events is given, nor are the listed events causally related to one another. Chronological sequencing is the sole organizing principle of the annals form. Chronicles, as the name implies, share this rudimentary organizing principle. But unlike an annalist, a chronicler focuses on a central subject, such as a personage, a town, or an institution, and includes only those events that bear on this subject $(1987,16)$. In addition to chronology, a discernible principle of selection organizes a chronicle. Moreover, chronicles furnish a greater quantity of information than annals (1987, 16). Like an annalist, however, a chronicler draws no conclusion about the meaning of the series of depicted events $(1987,16)$. In White's words, a chronicle 'aspires to narrativity' but falls short because of its 'failure to achieve narrative closure' - the selected series of events stops without ending $(1987,5)$. In contrast, 'history proper' attains 'full narrativity' in virtue of revealing events 'as possessing a structure, an order of meaning, that they do not possess as mere sequence' $(1987,5)$. The central question of White's essay is what kind of meaning a full-fledged narrative confers on events - that is, how narrative closure is accomplished.

Missing from the world of the chronicler but present in that of the historian is law or morality. According to White, every historical narrative aims to 'moralize the events of which it treats' and stems from a 'desire to moralize reality, that is, to identify it with the social system that is the source of any morality we can imagine' $(1987,14)$. Citing Hegel, White suggests that the reality that 'lends itself to narrative representation is the conflict between desire and the law' (1987, 12-13). The subject of a full-fledged narrative is a struggle pitting a dissident agent against moral/legal authority. It ends with a 'passage from one moral order to another' $(1987,23)$.
Only the determination that the last event in the chronological sequence is just or unjust can convert a termination into an ending and thereby secure closure.

One of my doubts about White's account concerns the claim that moral judgment is necessary for narrative closure. Assuming that closure is a necessary feature of full-fledged narrative, which is debatable, it nevertheless seems possible to produce a full-fledged narrative of a set of natural events and processes. ${ }^{13}$ Consider a story of the Precambrian ice age. It could invoke geological and climatic forces to explain what precipitated the prolonged plunge in temperature and why warmer conditions eventually developed. It could conclude by describing an altered but stable balance of natural forces. The advent of a new environmental equilibrium could provide closure for this narrative of a geochronological period.

My point holds for stories about human affairs as well as for stories about nonhuman nature. Consider, for example, relatives of a victim of state terrorism whose only demand is that the body of the victim be located and returned to family members for burial. They seek emotional closure, and the story of the rupture of their familial bonds, their search for the remains, and their grave-side mourning makes sense as a full-fledged narrative. Through the funeral ritual, they restore their ties to the victim and come to terms with their loss. Sometimes the relatives of a victim of state terrorism demand only to know what happened to the victim - e.g., that she was flown out over the ocean and thrown from the helicopter in shackles. They seek epistemic closure, and the story of the mysterious disappearance of a family member, the survivors' quest for information, and the revelation of the truth makes sense as a full-fledged narrative. Neither of these stories breaks off at some arbitrary point. By recuperating and completing an emotional relationship or by gaining crucial knowledge, they attain closure.

Moral closure is not the only kind of narrative closure. ${ }^{14}$ Still, White is onto something important, for moralization seems to be an ever-present temptation in story-telling. Many people succumb to an impulse to moralize natural phenomena by importing divine purpose and agency into their world views or by anthropomorphizing and sentimentalizing nature. The temptation to moralize stories is redoubled in stories of emotional or epistemic closure, for they commonly depict events that have morally significant dimensions. It is natural, for instance, to say that the family of a terror victim whose persistence finally sparks an investigation and disclosure of the victim's fate has won a moral victory over official obfuscation or indifference. ${ }^{15}$ Nevertheless, it would be misleading to conflate every form of human resolution with moral resolution. There are emotional, epistemic, and pragmatic forms of closure that are not equivalent to moral closure.

\subsection{White's Model and Victims' Stories}

If moral closure is not a necessary feature of full-fledged narratives, we must ask whether normative content is implicated in victims' stories at all. My discussion of White points to two problematic possibilities. On the one hand, a victim's story of suffering and surcease might reach pragmatic, emotional, or epistemic closure. 
From the standpoint of these values, a victim's story can be complete without moral resolution. Because the story achieves at least one of these kinds of closure, the audience may find nothing missing and experience it as a complete whole. As a result, it may not be registered as making any moral demand on its audience apart from the respect due to any speaker. On the other hand, the temptation to moralize emotional, epistemic, and pragmatic closure explains why telling victims' stories can be so useful and also so risky. Audiences can read the need to punish abusers or to augment legal protections into the story, but they can also read negligence or fault on the part of the victim into the story and assign blame to that individual. If ensuring that victims are empowered to tell their own stories in their own voices is to function as an effective human rights tool, story tellers must avoid these pitfalls.

White's demarcation of three levels of narrativity provides another viewpoint from which to grasp both the dangers and the benefits of storytelling as a strategy for advancing human rights. That many victims' stories fail to satisfy White's criteria for annals, chronicles, or full-fledged narratives clarifies what is at stake in the relationship between victims' stories and moral closure.

Nora Strejilevich sketches a familiar picture of the stories many victims of human rights violations tell: They contain 'discontinuities, blanks, silences, and ambiguities' $(2006,704) .{ }^{16}$ Such stories resemble annals both in their form and in their genesis. Annals enumerate events but leave whatever connections there may be among them unspecified. The hostile conditions that give rise to annals bring acute neediness and imminent death to the forefront of their authors' consciousness and deprive them of cognitive space for theorizing the course of the events they report (1987. 10-11). The horrific, not to say unspeakable, suffering that gives rise to annals-style victims' stories coincides with White's analysis of the source of the annals form.

But the victims' stories Strejilevich describes also resemble chronicles, for although they are by no means comprehensive, they are unified by a central subject - a suffering person. ${ }^{17}$ Although varying peripheral details - e.g., the color of a room where violence occurred - may be mentioned in different tellings of the story, the invariable core events are major harms the narrator has endured at the hands of others (Herlihy et al., 2002). Even victims' stories that are marked by sporadic recall and disjointed presentation exhibit this determinate principle of selection.

In my view, this common type of victim's narrative is a hybrid form. Because these stories are organized around a topic, they report a less random selection of incidents than annals. Yet they do not supply sufficiently detailed and copious information to qualify as chronicles.

Neither annals nor chronicles reach moral closure. Presumably, they do not reach pragmatic, emotional, or epistemic closure either. Yet, those victims' stories that fit Strejilevich's profile strive for emotional closure. They are a means of 'working through traumatic loss' - putting the suffering in the past and regaining a present that is not overwhelmed by the past $(2006,701,706-707,708$; also see Brison 2002, 103). When successful in this endeavor, these stories, like full-fledged narratives, achieve emotional closure.
Strejilevich adds that these stories are a means for 'social and cultural resistance' and thus for the 'ethical recovery of a community' $(2006,707)$. This has the ring of moral closure. But what Strejilevich describes is not the closure of acknowledgment, restitution, or protection from future wrongs. Rather, she holds that 'the truth told in testimony, even if it cannot stop the reiteration of such crimes, is one of the reservoirs of dignity left for humanity' (2006 706). Rather than achieving moral closure, these stories contribute to a practice of maintaining awareness of the meaning of atrocity and the need for vigilance if renewed brutality is ever to be thwarted. They signify an existential repudiation of bad faith, which keeps a thorn in the side of complacency.

It seems that Strejilevich has given up hope of moral closure. Borrowing from Shoshana Felman, she calls victims who tell their stories 'post-narrators' (2006, 713). Yet, their post-narratives share features of annals, chronicles, and full-fledged narratives (if you agree with me that emotional closure suffices for narrative closure). In my judgment, there is much to be gained by thinking of these stories as hybrid narratives and exploring whether some form of moral closure is possible and desirable.

\subsection{Varieties of Moral Closure}

Empirically, Strejilevich's wariness of moral closure and her circumspection about the power of victims' stories to advance human rights stems from post-Holocaust, post-Nuremberg history. International treaties and human rights documents have promulgated reforms, but this new moral order is honored as much in the breach as in observance. Genocide, mass rape, torture, and 'disappearances' continue al but unabated and seldom punished. All of this despite the steady stream of victims' stories in the media and in national and international tribunals.

If moral closure for victims' stories means putting human rights abuses in the past by putting an end to them, no victim's story has ever achieved moral closure. But this conception of moral closure idealizes and mystifies moral closure by giving it a utopian, absolutist twist. ${ }^{18}$ If the concept of moral closure is to be of any use in interpreting human affairs and setting human goals, it cannot require achieving perfect subjective, interpersonal, juridical, or social harmony. Moments of moral closure are just that - moments in a life, moments in a relationship, moments in a legal system or social history. ${ }^{19}$ Any instance of moral closure is an incomplete, non-definitive rapport that arises from a particular history and reflects the needs of a particular present. ${ }^{20}$ Whatever their merits, the understandings and arrangements that constitute moral closure eventually crack open revealing flaws in perception, understanding, or moral imagination. Think of moral closure, therefore, as a respite that temporarily allows a person or a society to attend to other matters.

Hayden White is responsible for another misconception. ${ }^{21}$ As a legalistic moral conventionalist, White is suspicious of the moral closure of full-fledged narrative. In his view, moralizing reality is necessary to achieve moral closure, and to moralize reality is to indulge in a kind of fabulism that is in thrall to hegemonic 
norms. Full-fledged narratives suffuse reality with norms that are generated and sustained under the aegis of political power and that determine how outcomes are evaluated. In one respect, White's distrust of moral closure is warranted. If presumed to follow from indubitable norms, moral closure underwrites moral stagnation and quashes destabilizing voices. ${ }^{22}$ But this assumption is baseless, and it's doubtful that White endorses it, for he maintains that a passage from one moral order to another is the only intelligible form that narrative closure can take $(1987,23){ }^{23}$ If so, the state cannot be the only source of moral norms, and moral closure cannot be permanent.

Amsterdam and Bruner propose an explicitly elastic conception of moral closure. They note that there are ambiguous scripting situations - situations where it isn't obvious which script applies - and that these situations prompt reflection about how to finesse the constraints of well-trodden plot paths and arrive at suitable endings $(2000,112)$. These situations implicitly call the status quo ante into question and oblige decision-makers to entertain the possibility that nothing less than creating a 'new (transformed) steady state' will suffice. If such a story does not constitute an altogether new 'legal genre,' it at least constitutes a significant reinterpretation of an existing genre - that is, an enlarged class of wrongs and potential victims and an enlarged basis for litigation. ${ }^{24}$ There is moral closure, but there is no finality. ${ }^{25}$

Building on this line of thought, Bruner argues that narrative genres are not only 'tools of narrative problem solving' but also tools of 'problem finding' ( 2002 , 20). Thus, he countenances two types of moral closure. A problem solving narrative concludes with a coda that delivers a lesson. It mandates a norm or practice. In contrast, a problem finding narrative concludes with a coda that enunciates a plight. Its reveals a here-to-fore hidden type of moral perplexity. For Bruner, then, one form of moral closure is achieved through the representation of a moral problem.

This brings us closer to grasping the relation between victims' stories and moral closure. But there is another source of confusion that needs to be addressed. It is important to keep personal, legal, and social closure separate from narrative closure. But it is easy to conflate them because narratives can recount a process through which psychological, legal, or social closure has been reached and because telling stories often functions as a means to reaching psychological, legal, or social closure. People tell themselves stories in order to satisfy themselves that they did no wrong, and they also tell stories about how they developed the narrative that enabled them to accomplish this aim. But unless you subscribe to an ontology in which discourse is the only reality, the psychological sense of moral resolution is not identical to the story you tell yourself, and the moral resolution is not identical to the story of producing that story.

There are several ways in which victims of human rights violations can attain personal moral closure. ${ }^{26}$ First, they can obtain moral vindication by getting a fair judgment from a court or by negotiating a fair disposition of their claims. Here moral closure is expressed by 'I'm satisfied with the compensation I've received, and I'm ready for a fresh start.' Second, they can seek moral rapprochement.
This form of moral closure is expressed by 'I've purged myself of anger and hatred, and I forgive my tormenters.' Third, they can discharge moral obligations they believe they have incurred as a result of their ordeal - such as, helping to bring wrongdoers to justice or bearing witness to what has happened and speaking for those who perished. 'I've done what I can, and I've done enough' expresses this form of moral closure.

Telling a story of reaching personal moral closure is a direct route to narrative moral closure. Such a story may fit comfortably into the Amsterdam/Bruner template, and I don't think Strejilevich would deny this possibility. More elusive is the potential for moral closure in victims' narratives that don't have satisfying moral endings - where no compensation can be adequate, where forgiveness is impossible, or where the responsibility to the dead is so enormous that it can never be fulfilled. At this point, it's tempting to appropriate Bruner's literary conception of moral closure as the articulation of a plight. And doing so would be justified to some extent, for the hybrid, fragmented victims' stories that Strejilevich characterizes have indeed revealed the immensity of human savagery and the depths of human depravity, and they have also conveyed the agony of Post-Traumatic Stress Disorder. However, Bruner's view seems to sidestep the issue, for it is an odd sort of narrative closure that leaves its audience in suspense.

\subsection{Moral Closure without Moral Resolution}

Here it is useful to revisit White's account of the annalist and the central subject of a chronicle as they apply to hybrid, fragmented victims' stories. The annalist, recall, is a person in the grip of consuming fear and abject wretchedness. The central subject of a hybrid, fragmented victim's story is also a suffering person. However, unlike annalists who are so overwhelmed by suffering that their lives lack agency and meaning, the narrators of victims' stories do not encounter or represent a normatively neutral world. Just as third-person chroniclers choose to include events based on their relevance and importance to their topics, so too a first-person narrator of victimization selects events that caused the author/speaker to suffer and represents them as normatively significant.

People who suffer unwillingly and avoidably at the hands of malefactors experience suffering as bad - typically as terrifying and debasing, as well as tormenting. ${ }^{27}$ In their stories, though, they may refrain from overtly moralizing - pointing fingers at villains or denouncing others' misdeeds. Because such explicit pronouncements can flatten and oversimplify the moral significance of the abuse they have undergone, they may instead rely on various rhetorical devices to convey the normative inflection of their experience. I think this is what Strejilevich has in mind when she affirms both the 'poetic voice' and the narrative structure of hybrid victims' stories $(2006,704,708)$. In delineating character, in the pacing and punctuation of episodes, in silences and gaps, in figurative language, and in tone, victims convey the normative significance of the events they portray. Narrative time - the cadence of the story - may slow to linger on particularly painful or important incidents. 
Scattered shards of detail may signal insupportable pain - suffering so excruciating that it defeats unbroken awareness. Recourse to figures of speech may signal brutality so vile that it defies ordinary descriptive categories. ${ }^{28}$ The performative dimension of oral story-telling - including the emotional tenor of a speaker's demeanor, whether phrasing is smooth or spasmodic, and how the timbre of voice is pitched - extends the capacity of victims' stories to dramatize normative significance. ${ }^{29}$

To achieve closure, a story must reach a recognizable state of completion. Narrative closure - regardless of whether the narrative is a conventiona Amsterdam/Bruner-style narrative or a hybrid Strejilevich-style narrative and regardless of whether the closure is pragmatic, emotional, epistemic, or moral is never solely a function of the text. It presupposes extensive background information and shared cultural norms that together give rise to expectations. In turn, these expectations generate a sense that the story is complete or has loose ends (Bennett 1997). Since every form of narrative closure depends on systems of beliefs and values that audience members must bring to the text if anyone is to comprehend it, the question of how moral closure is possible for hybrid, fragmented victims' narratives poses a pair of problems. First, what kind of moral completion is appropriate to their subject matter and their structure? Second, what frameworks render such exposition cogent and underwrite judgments about completeness?

These stories recount inflicted harm so horrendous that their narrators have not been, arguably cannot be, adequately compensated, nor can their perpetrators be proportionately punished. Since any individualized remedy would be too paltry in comparison with the monstrosity of the crime, none could secure personal mora closure. Likewise, no description of such a remedy could secure narrative moral closure. If moral closure is possible for hybrid, fragmented narratives, it must be a different species of closure from mundane legal provisions for conflict resolution. I propose that a victim's story that successfully represents a moral void together with an implicit moral imperative that has been systematically abrogated achieves this alternative kind of moral closure. Such a victim's narrative fully expresses a moral demand. ${ }^{30}$

This appeal to conscience consists in nothing more than a compelling articulation of what the narrator has endured. ${ }^{31}$ Now, it might seem that the moral demand is a consequence of a formal defect in the victim's story - namely, the absence of a morally gratifying ending. On this view, narrative moral closure depends on real-world moral closure to supply an ending and complete the story. To adopt this approach, however, is just to insist that White's full-fledged narratives and Amsterdam and Bruner's problem-solving narratives exhaust the category of morally complete narratives. But confining the concept of moral closure to these formats does an injustice to many story-tellers and arbitrarily excludes some orthodox narrative forms. Consider parables and allegories - narratives that are complete in themselves and that express moral meaning without explicitly stating it. That these literary forms require interpretation to discern their normative significance is no reason to deny that they can achieve moral closure, and, in my view, the same goes for hybrid, fragmented victims' stories.
Further justification for admitting the form of moral closure I'm ascribing to hybrid, fragmented narratives comes from the fact that we can specify the background frameworks that make it possible to interpret them in a morally attuned way and that thus make moral closure possible for them. Chief among them are everyday interpersonal psychology, basic literary competence, and human rights discourse. Knowledge of human psychology is necessary to grasp the horror of the experiences that victims depict - that is, to comprehend the psychocorporeal torture and terror the victim suffered. Literary competence is necessary to appreciate individualized as opposed to formulaic expression and to decode the lyric, allusive, metaphoric language in which the victim may couch a normative claim. Familiarity with human rights is necessary to provide a vocabulary in which a moral practice that answers to the story-teller's suffering can be envisaged and advocated. These frameworks supply criteria that enable listeners/readers as well as the narrators themselves to judge whether hybrid, fragmented victims' stories are morally complete or not. When people - whether audience members or narrators - fail to discern moral closure in hybrid, fragmented victims' stories, it is an open question whether the problem stems from flaws in the narrator's text or deficient human rights literacy. ${ }^{32}$

What I am suggesting is that a full account of moral closure for the hybrid, fragmented stories that victims of dehumanizing abuse often tell depends on developing an aesthetics of morally valuable representations of extreme moral disvalue. Although there is nothing arcane about the frameworks that render the moral import of these stories intelligible, it is by no means obvious how to theorize the capacity of these stories to contribute to debates over the meaning of human rights. Nor is it obvious how a case can be made for regarding them as legitimate forms of legal discourse. Important as these issues are, I must leave them for another occasion.

Here, I conclude only that moral closure is both possible and desirable for hybrid, fragmented victims' stories. Aristotle claims that a well constructed story 'must represent, one action, a complete whole' and that moral considerations are intrinsic to representations of human action (1947, Poetics, 1151a 30, 1450b 5-10). My view parallels Aristotle's, for I am suggesting that one way in which a victims' story can be morally complete is to represent a complete experience and that a sequence of assaultive incidents stripped of any moral dimension is inconceivable. Whether because she models moral closure on the theories of Amsterdam and Bruner or White, or for some other reason, Strejilevich underestimates the potential of victims' stories to advance human rights discourse. Telling these stories is not merely a matter of gaining emotional closure, confronting grisly truths, or eschewing bad faith. It is the fulfillment of a vital task in critical moral reflection - namely, issuing a clarion moral appeal.

Acknowledgments I presented this paper at the FEAST 2007 Conference in Clearwater Springs FL and to the Philosophy Department at Loyola University, Chicago, and I would like to thank both audiences for their comments. I owe a great debt of gratitude to the University of Connecticut Human Rights Institute for awarding me a fellowship that enabled me to write this paper and also to the members of the workshop group on narrative, humanity, and humanitarianism funded by 
the University of Connecticut Foundations of Humanitarianism Program for the periodic discussions that prompted me to start thinking along the lines developed in this paper. Finally, I thank Susan Shepler for sharing her invaluable unpublished manuscripts with me. Her work has greatly advanced my thinking about this topic.

\section{Notes}

1. See, for example, MacKinnon (1989)

2. See, for example, hooks (1997); King (1997); Narayan (1997)

3. See, for example, Delgado (1989).

4. See, for example, Walker $(2003,2006)$.

5. See, for example, Matsuda (1993) and Meyers (1994).

6. See, for example, Code (1991) and Govier (1993a, b, 2005).

7. See Amsterdam and Bruner (2000); Bruner (1990, 2003); Cover (1983); White (1987). Nelson (now Lindemann) (2001) and Danto (1985) are exceptions to this trend. In characterizing narratives, neither cites normative features.

8. Another complication is that some victims' stories tell of witnessing rather than undergoing alleged human rights violations. Although I appreciate the value and power such narratives can have, in the interest of parsimony I limit the discussion that follows to narratives of alleged human rights violations that purport to recount harms inflicted on the narrator her-/himself.

9. I'm not sure whether Amsterdam and Bruner would contest my point. They claim that their definition is 'austere' and that it specifies 'what is necessary to make a story,' which suggests that they do not regard their account as stipulative or as explicating one of many narrative structures (2000 113). If this is their position, I think it's too restrictive.

10. Susan Slyomovics also documents the inhibition of women's testimony about rape in postApartheid South Africa and after the death of King Hassan II in Morocco (Slyomovics 2005, $81,85,87)$.

11. For discussion of the need for this kind of contextualization in subversive narratives, see Ewick and Silbey $(1995,218-220)$. In a situation with interesting parallels to and differences from Shepler's case, Schaffer and Smith analyze how the stories of women who were abducted by the Japanese and turned into 'comfort women' during WWII lost relevant contextual information $(2004,134-146)$.

12. For valuable discussion of controversies concerning traditional justice and transitional justice, see 'Reparations, Truth, and Reconciliation' (in Soyinka 1999).

13. For doubts about the necessity of closure, see Rimmon-Kenan (2006).

14. In White's defense, it might be argued that he is concerned exclusively with historical narratives and that my counter-examples cite scientific and personal narratives. However, this rejoinder doesn't withstand scrutiny. A historical narrative could achieve closure by explaining how causal forces brought about an altered distribution of power and/or the institution of novel social, political, or, economic structures. Moreover, White's text strongly suggests that his views do not apply solely to historical narratives. In his discussion of the moralization of reality and the state's role as the source of norms, he observes, 'And this raises the suspicion that narrative in general, from the folktale to the novel, from the annals to the fully realized "history," has to do with the topics of law, legality, legitimacy, or more generally, authority" $(1987,13)$. Later, he maintains, 'Where, in any account of reality, narrativity is present, we can be sure that morality or a moralizing impulse is present too' $(1987,24)$

15. For groundbreaking work on the relations between epistemic, emotional, and moral closure, see Walker (2006).

16. The 'discontinuities' can be dramatic and heartrending. Shoshana Felman describes K-Zetnick's collapse on the witness stand at the 1961 Eichmann trial in Jerusalem (Felman
2002, 135-137). Susan Slyomovics describes the 'unbearable' screams of Nomonde Calata, who broke down while giving testimony on the second day of the South African Truth and Reconciliation Commission in 1996, and the 'wrenching' screams of Maria Charaf upon hearing a recording of her dead husband's voice at the first public commemoration of his death in Casablanca in 1999 (Slyomovics 2005, 73-76).

17. On the issue of comprehensiveness, Strejilevich observes that such narratives are 'incapable of exhibiting all the horror,' and she rejects demands for 'total exposure' (2006, 207). Thus, some victims' stories do not measure up to one of the presumed advantages of chronicles over annals.

18. In arguing that closure is an artifact of narrative and doesn't exist in the real world, White assumes that closure consists of a final ending (White 1987, 23-24). Pointing out that events don't come to an end, he urges that closure can only be moral and that morality is a function of the imagination, not a feature of the world.

19. In this respect, there is no difference between moral closure and pragmatic, epistemic, and emotional closure. All are temporary, at least in my experience.

20. I adopt the term 'rapport' here following Montesquieu, who, according to Hannah Arendt, defines laws as rapports (Arendt 1998, 190).

21. Strejilevich cites White's work in connection with issues of objectivity and truth, but she does not take up his taxonomy of narratives or his views about moral closure.

22. Put another way, definitive moral closure amounts to repudiating what Ronald Dworkin calls the 'interpretive attitude' $(1986,47-52)$. Adopting the interpretive attitude towards social and legal norms authorizes individuals and public officials to reconsider norms in light of the purpose they are supposed to serve.

23. In my view, White exaggerates the finality of narrative closure when he is arguing that moral closure is the only possible form of narrative closure, but he concedes that no closure is definitive when he is arguing that the annals and chronicle forms more accurately represent reality.

24. As Amsterdam and Bruner remark, 'Perhaps it is because they have the power to expand the boundaries of possibility that the invention of new literary or political or legal genres is so important' $(2000,133)$.

25. To explain normative change, Amsterdam and Bruner advert to what they call the 'dialectic of culture' $(2000,231$; also see Bruner 2002, 13-14). This is the familiar idea that because cultures are not homogeneous, the norms they espouse are the results of ongoing contestation and negotiation among members of the group and within the group's institutions. It is surely true that intra-cultural disagreement sparks negotiation and change in a culture's canonical conceptions of legitimate ordinariness, wrongdoing, and fair solutions. However, I do not have space here to analyze exchanges between changes in the larger cultural context and specifically legal changes.

26. For relevant discussion, see Walker (2006)

27. By setting up the conflict that paradigmatically inspires narrative as a conflict between desire and law, White trivializes victims' suffering and neglects its importance for narrative theory. His insistence that the state is the only conceivable purveyor of moral norms compounds this His insistence

28. For rhetorical analysis of some women's testimony in the first few days of the South African TRC, see Ross (2001, 260-266).

29. At one point, the transcript of Nomonde Calata's 1996 testimony at the TRC reports an interval of sobbing in brackets and the announcement of a recess. What happened is that she broke down, wailing in anguish,' and radio listeners found her screams so piercing that they turned off their radios to flee (Slyomovics 2005, 73). Although the transcript is a technically accurate record, it fails to communicate the normative significance of this part of her testimony. Worse, it gives the misleading impression that her testimony stopped at this point and continued later - as if her sobs were extraneous to her story.

30. I see my proposal as supplying a practical interpretation of White's rather obscure claim that narrative mediates between the real and the imaginary and Cover's similar claim that narrative mediates between the actual and the possible or utopian (White 1987, 4; Cover 1983, 9-10). 
31. I caution that a hybrid, fragmented victim's story that achieves narrative moral closure in the sense I present here may, but need not facilitate psychological closure for the victim.

32. I leave aside the less common possibilities of psychological obtuseness and literary ignorance.

\section{References}

Amsterdam, A.G. and J. Bruner. 2000. Minding the Law (Cambridge MA: Harvard University Press).

Arendt, H. 1998.The Human Condition (Chicago: University of Chicago Press).

Aristotle. 1947. Poetics. In Introduction to Aristotle. Ed. R. McKeon. Trans. I. Bywater (New York. Modern Library).

Bennett, W.L. 1997. 'Storytelling in Criminal Trials: A Model of Social Judgment.' In Memory, Identity, Community: The Idea of Narrative in the Human Sciences. Eds. L.P. Hinchman and S.K. Hinchman (Albany, NY: SUNY Press).

Brison, S.J. 2002. Aftermath: Violence and the Remaking of a Self (Princeton NJ: Princeton University Press).

Bruner, J. 1990. Acts of Meaning (Cambridge, MA: Harvard University Press).

Bruner, J. 2002. Making Stories: Law, Literature, Life (Cambridge, MA: Harvard University Press).

Code, L. 1991. What Can She Know? Feminist Theory and the Construction of Knowledge (Ithaca NY: Cornell University Press).

Cover, R.M. 1983. 'Nomos and Narrative.' Harvard Law Review97 (4): 4-68.

Danto, A.C. 1985. Narration and Knowledge (New York: Columbia University Press).

Delgado, R.1989. 'Legal Storytelling: Storytelling for Oppositionists and Others: A Plea for Narrative.' Michigan Law Review 87: 2411.

Dworkin, R. 1986. Law's Empire (Cambridge, MA: Harvard University Press)

Ewick, P. and S.S. Silbey. 1995. 'Subversive Stories and Hegemonic Tales: Toward a Sociology of Narrative.' Law and Society Review29: 197-226.

Felman, S. 2002. The Juridical Unconscious: Trials and Traumas in the Twentieth Century (Cambridge MA: Harvard University Press).

Govier, T. 1993a. 'Trust and Testimony: Nine Arguments on Testimonial Knowledge.' International Journal of Moral and Social Studies 8 (1):21-39.

Govier, T. 1993b. 'When Logic Meets Politics: Testimony, Distrust, and Rhetorical Disadvantage.' Informal Logic. 15: 93-104.

Govier, T. 2005. 'Truth and Storytelling: Some Hidden Arguments.' In Uses of Argument: Proceedings of a Conference at McMaster University. Ed. D. Hitchcock (Hamilton: McMasters University).

Herlihy, J., P. Scragg, and S. Turner. 2002. 'Discrepancies in Autobiographical Memories - Implications for the Assessment of Asylum Seekers: Repeated Interviews Study. 324-327.

hooks, b. 1997. 'Sisterhood: Political Solidarity between Women.' In Feminist Social Thought: A Reader. Ed. D.T. Meyers (New York: Routledge).

King, D.K. 1997. 'Multiple Jeopardy, Multiple Consciousness: The Context of Black Feminist Ideology.' In Feminist Social Thought: A Reader. Ed. D.T. Meyers (New York: Routledge).

MacKinnon, C.A. 1989. Toward a Feminist Theory of the State (Cambridge, MA: Harvard University Press).

Matsuda, M. 1993. 'Public Response to Racist Speech: Considering the Victim's Story.' Words That Wound. Ed. M. Matsuda, et al. (Boulder, CO: Westview Press).

Meyers, D.T. 1994. Subjection and Subjectivity: Psychoanalytic Feminism, and Moral Philosophy (New York: Routledge).

Mills, C. 1998. Blackness Visible: Essays on Philosophy and Race (Ithaca NY: Cornell University Press).

Narayan, U. 1997. Dislocating Cultures (New York: Routledge).
Nelson, H.L. 2001. Damaged Identities; Narrative Repair (Ithaca NY: Cornell University Press).

Rimmon-Kenan, S. 2006. 'Concepts of Narrative.' In The Travelling Concept of Narrative: Studies across Disciplines in the Humanities and Social Sciences. Eds. M. Hyvärinen, A. Korhonen, and J. Mykkänen (Helsinki: Helsinki Collegium for Advanced Studies).

Ross, F.C. 2001. 'Speech and Silence: Women's Testimony in the First Five Weeks of Public Hearings of the South African Truth and Reconciliation Commission.' In Remaking a World:Violence Social Suffering and Recovery. Ed. V. Das, et al. (Berkeley CA: University of California Press).

Schaffer, K. and Sidonie S. 2004. Human Rights and Narrated Lives: The Ethics of Recognition (New York: Palgrave).

Shepler, S. 2002. 'Les Filles Soldats: Trajectoires d'apres-guerre en Sierra Leone.'Politique Africaine 88: 49-62 (my citations refer to the English language version of this article in manuscript for which I thank Susan Shepler).

Shepler, S. 2006. 'Can the Child Soldier Speak?' Conference on Humanitarian Responses to Narratives of Inflicted Suffering (University of Connecticut, Storrs. October 13-15, 2006).

Slyomovics, S. 2005. 'The Argument from Silence: Morocco's Truth Commission and Women Political Prisoners.' Journal of Middle East Women's Studies. 1 (3): 73-95.

Soyinka, W. 1999. The Burden of Memory, the Muse of Forgiveness (New York: Oxford University Press).

Strejilevich, N. 2006. 'Testimony: Beyond the Language of Truth.28 (3): 701-713.

Walker, M.U. 2003. 'Truth and Voice in Women's Rights.' In Recognition, Responsibility, and Rights. Eds. R.N. Fiore and H.L. Nelson (Lanham MD: Rowman and Littlefield).

Walker, M.U. 2006. Moral Repair: Reconstructing Moral Relations after Wrongdoing (Cambridge: Cambridge University Press)

White, H. 1987. 'The Value of Narrativity in the Representation of Reality.' In The Content of the Form: Narrative Discourse and Historical Representation (Baltimore, MD: Johns Hopkins University Press). 